\title{
ROZDZIAŁ 16
}

\section{Restrukturyzacja firm wchodzących na rynki zagraniczne}

\author{
Beata Glinkowska*
}

\subsection{Wprowadzenie}

Przedsiębiorstwa rozwijające się, zwłaszcza niewielkie, częściej zmieniają strukturę organizacyjną niż te, które osiągnęły pewien status i zamierzają go utrzymać. Zarówno rozwój, jak i utrzymanie status quo są zależne od strategii firmy, ta zaś od wizji i charyzmy jego właścicieli czy kierowników. Według A. D. Chandlera [1962] istnienie zgodności pomiędzy zmiennymi, takimi jak strategia, struktura organizacyjna i otoczenie firmy, jest powodem wyższej efektywności. Można zatem wnioskować, że strategie bazujące na odpowiednich strukturach organizacyjnych pozwolą lepiej wykorzystać szanse istniejące w otoczeniu. Jest to ważne dla wszystkich przedsiębiorstw, jednak w przypadku ich wchodzenia na rynki zagraniczne wydaje się to sprawą szczególnej wagi. Wyjście ze swoją działalnością poza granice kraju prawie zawsze wiąże się $\mathrm{z}$ dokonaniem restrukturyzacji $\mathrm{w}$ celu optymalnego dopasowania struktury do nowych i często mało znanych warunków funkcjonowania. W świetle praktyki restrukturyzacja wydaje się metodą doskonalenia funkcjonowania przedsiębiorstw. Struktura zaś jest instrumentem zarządzania [Kaczmarek, Sikorski 1999, s. 49]. Wiele jest motywów dokonywania restrukturyzacji. Niektóre z nich wskazano w niniejszym rozdziale. Proces restrukturyzacji firm wchodzących na rynki zagraniczne został opisany na podstawie literatury przedmiotu, a także przeprowadzonych badań, opartych na wywiadach z kadrą kierowniczą oraz właścicielami czterech firm $\mathrm{z}$ województwa łódzkiego $\mathrm{z}$ branży odzieżowej (przedsiębiorstwa usługowo-produkcyjne - firmy małe) i spożywczej (hurtownia, magazyny - firmy średnie), które rozpoczynały bądź prowadziły już działalność poza granicami Polski. W kwestii przyczyn oporu wobec zmian restruk-

${ }^{*}$ Dr, adiunkt, Uniwersytet Łódzki, Katedra Zarządzania. 
turyzacyjnych zbadano dobranych losowo pracowników tych organizacji, w których autorka przeprowadzała restrukturyzację (około 30 pracowników z 9 firm z sektora MSP). Celem rozdziału jest zatem opisanie wniosków będących wynikiem analizy procesu wprowadzania zmian restrukturyzacyjnych $\mathrm{w}$ związku $\mathrm{z}$ wchodzeniem przedsiębiorstwa na rynki zagraniczne. W związku $\mathrm{z}$ tym autorka dokonała próby odpowiedzi na pytania dotyczące problemów badawczych:

- czy małe i średnie firmy w sytuacji zmniejszających się możliwości na rynku krajowym korzystają głównie z własnych zasobów ludzkich, co wiąże się z koniecznością zmian zakresów czynności, kompetencji i obowiązków;

- czy w praktyce w firmie stosuje się jeden rodzaj restrukturyzacji, czy też można spotkać jej typy mieszane;

- jakie są powody restrukturyzacji i czy występuje opór wobec przeprowadzanych zmian.

\subsection{Struktura organizacyjna i restrukturyzacja - istota, pojęcia}

Strukturą jakiejś konkretnej całości nazywa się zbiór stosunków pomiędzy jej poszczególnymi elementami [Zieleniewski 1976, s. 43]. Dotyczy ona zbioru stosunków organizacyjnych, mających znaczenie z punktu widzenia dążenia do realizacji celu. Wyrazem tego zbioru są więzi organizacyjne [Kaczmarek, Sikorski 1999, s. 89]. A Peszko [2002, s.20] zauważa, że struktura organizacyjna określa hierarchię służbową w organizacji. Struktura oznacza więc pewien układ (stosunek) stanowisk, komórek, działów, oddziałów itd. w zorganizowanej całości, którą jest przedsiębiorstwo. Zazwyczaj rozumie się ją jako schemat organizacyjny (zwany też organigramem), jednakże należy zauważyć, że jest to ujęcie statyczne. W dynamicznym ujęciu jest ona postrzegana przez pryzmat regulaminów, zasad, relacji, zależności, przyjęć do pracy, awansów, zwolnień, przesunięć itd., a także przez pryzmat zależności z firmami zewnętrznymi, posiadającymi własną strukturę i regulaminy [Wikipedia 2013].

Restrukturyzacja, inaczej transformacja czy przeobrażenie, kojarzy się najczęściej ze zmianą $\mathrm{w}$ różnych obszarach funkcjonowania firmy. W literaturze można odnaleźć różne definicje procesu restrukturyzacji, ale najczęściej odnoszą się one do zmian w majątku firmy i w źródłach jego finansowania (w aktywach i pasywach firmy) [Glinkowska 2013, s. 45]. Restrukturyzacja może dotyczyć zmian organizacyjnych niewielkich, stanowiskowych, ale też obszernych, dużych i kompleksowych. 


\subsection{Rodzaje restrukturyzacji}

Wyróżnia się kilka rodzajów restrukturyzacji. Najczęściej można spotkać się z planowaniem i przeprowadzaniem restrukturyzacji naprawczej, której potrzeba ujawnia się wówczas, gdy organizacja ma kłopoty finansowe [Stabryła 2000, s. 251-253]. Jest to trudna sytuacja, bowiem każda organizacja potrzebuje pieniędzy dla przeprowadzenia restrukturyzacji, co często pogrąża ją jeszcze bardziej. Zmusza to właścicieli i kierowników do szukania zewnętrznych źródeł finansowania, co zwiększa koszty funkcjonowania organizacji w związku z obsługą długu.

Kolejny rodzaj to restrukturyzacja antycypacyjna, dotycząca reorganizacji stanowisk pracy, zatrudnienia lub rentowności firmy. Polega ona głównie na obserwacji innych firm z branży w celu taniego i szybkiego zyskania gotowych rozwiązań (benchmarking) [Borowiecki, Kwieciński (red.) 2001, s. 25-26]. Jest to rodzaj restrukturyzacji mniej ryzykowny niż poprzedni, często też nie wymaga tak dużych nakładów finansowych.

Restrukturyzacja dostosowawcza (adaptacyjna) [Borowiecki, Kwieciński 2001, s. 25-26; Styn 2012, s. 129-130] jest zwykle przeprowadzana w organizacjach o zmniejszających się zyskach i rentowności. Polega ona na naprawianiu tych obszarów firmy, które są technologicznie i organizacyjnie przestarzałe oraz nierentowne.

Restrukturyzacja kreatywna (rozwojowa) ma charakter długofalowy, a jej skutki są widoczne zazwyczaj w przyszłości [Wikipedia 2013]. Polega ona na podjęciu działań zmierzających do wykreowania nowego produktu lub usługi. Ten rodzaj restrukturyzacji podejmują często firmy branż kreatywnych. Zazwyczaj jest ona powiązana ze stosowaniem w firmie strategii innowacji. Restrukturyzacja rozwojowa jest też najczęściej stosowaną metodą dla wyjścia przedsiębiorstwa poza granice kraju. Za jej podstawę przyjmuje się decyzje strategiczne związane z miejscem i siłą firmy w przyszłości [Stabryła 2000, s. 251-253].

C. Suszyński [2003, s. 128-138] wyróżnia także restrukturyzację operacyjna jako tę, która ma najszerszy zakres, bowiem może wiązać się z restrukturyzacją: marketingową, produktową, zasobów przedsiębiorstwa, techniczną i technologiczną.

Często spotykanym rodzajem jest także restrukturyzacja finansowa [Porada-Rochoń 2009, s. 80-100], określana jako proces oparty na gruntownej zmianie sposobu zarządzania finansami. A. Duliniec [2007, s. 118] zauważa, że jest ona podstawowym elementem postępowania naprawczego przedsiębiorstwa.

W procesie wchodzenia firmy na rynki zagraniczne najczęściej mamy do czynienia z restrukturyzacją kreatywną, czyli rozwojową. 


\subsection{Powody restrukturyzacji}

Istnieje wiele powodów dokonywania zmian organizacyjnych. W sektorze małych i średnich przedsiębiorstw najczęstszym powodem restrukturyzacji są mniejsze lub większe usprawnienia i modyfikacje [Glinkowska 2013]. Jest to jednak sformułowanie bardzo ogólne. Podobnie, ogólnym jest stwierdzenie, czemu te usprawnienia mają służyć. W odniesieniu do tego respondenci podawali: chęć wzrostu wartości firmy i podniesienia konkurencyjności, chęć utrzymania się na rynku. Trudno to generalizować, zwłaszcza że w jednej i tej samej organizacji może być kilka powodów restrukturyzacji. W świetle przeprowadzonych badań wydaje się, iż wprowadzanie w organizacji zmian ewolucyjnych (drobnych i często powtarzających się) jest bezpieczniejsze niż wprowadzanie zmian rewolucyjnych (dużych, kompleksowych). Istniejące przyczyny restrukturyzacji można umieścić w dwóch grupach: wewnętrzne i zewnętrzne (tab. 16.1).

Tabela 16.1. Wewnętrzne i zewnętrzne przyczyny restrukturyzacji firm

\begin{tabular}{|l|l|}
\hline \multicolumn{1}{|c|}{ Przyczyny o charakterze wewnętrznym } & \multicolumn{1}{|c|}{ Przyczyny o charakterze zewnętrznym } \\
\hline $\begin{array}{l}\text { Wzrost kosztów wytwarzania produktów/ } \\
\text { usług. }\end{array}$ & Wzrost konkurencyjności firmy. \\
\hline $\begin{array}{l}\text { Nadmierna energo- i materiałochłonność pro- } \\
\text { dukcji. }\end{array}$ & $\begin{array}{l}\text { Chęć poszerzenia działalności na rynki za- } \\
\text { graniczne. }\end{array}$ \\
\hline $\begin{array}{l}\text { Zużycie moralne maszyn; zużycie technolo- } \\
\text { giczne maszyn. }\end{array}$ & $\begin{array}{l}\text { Pojawienie się nowych technologii wytwa- } \\
\text { rzania. }\end{array}$ \\
\hline Wyraźny spadek motywacji pracowniczej. & Nasycenie rynku. \\
\hline $\begin{array}{l}\text { Niedopasowanie struktur organizacyjnych do } \\
\text { potrzeb (za dużo ludzi, za mało ludzi, brak } \\
\text { odpowiednich kompetencji u pracowników, } \\
\text { sztywność struktur itp.). }\end{array}$ & $\begin{array}{l}\text { Zmiana przepisów prawa wymuszająca } \\
\text { nową organizację pracy. }\end{array}$ \\
\hline Poszerzenie oferty handlowej. & Zmiana gustów i preferencji klientów. \\
\hline $\begin{array}{l}\text { Chęć rozwoju firmy: oddziały, filie w Polsce } \\
\text { i poza granicami. }\end{array}$ & Wystąpienie kryzysu. \\
\hline Zmiana polityki gospodarczej firmy. & Wystąpienie niżu demograficznego. \\
\hline $\begin{array}{l}\text { Wejście do zarządu firm młodych członków } \\
\text { rodzin (w drodze sukcesji). }\end{array}$ & $\begin{array}{l}\text { Pojawiające się szanse w przepisach prawa } \\
\text { na danym rynku zagranicznym. }\end{array}$ \\
\cline { 2 - 2 } & $\begin{array}{l}\text { Przebywający za granicą znajomy, przyja- } \\
\text { ciel, członek rodziny. }\end{array}$ \\
\hline
\end{tabular}

Źródło: opracowanie własne na podstawie przeprowadzonych badań. 
W tab. 16.1 zawarte zostały najczęściej wymieniane przez menedżerów (właścicieli) i najbardziej typowe powody/przyczyny przeprowadzania restrukturyzacji w sektorze małych i średnich przedsiębiorstw. Po podjęciu decyzji o restrukturyzacji należy przystąpić do jej realizacji. Przeprowadzanie tego procesu powinno być przemyślane, zaplanowane i szczegółowo przygotowane. Jednak nawet najlepiej zaplanowana reorganizacja wiąże się z oporem pracowników.

\subsection{Przyczyny oporu}

Uczestnicząc w kilkunastu restrukturyzacjach w firmach, zauważono, że istnieje wiele przyczyn oporu (sprzeciwu) wobec zmian. Opór pozostaje zwykle w ścisłym związku ze stanem wiedzy o planowanej restrukturyzacji: im więcej informacji i wiedzy mają pracownicy na temat sytuacji problemowej i proponowanych rozwiązań, tym opór jest mniejszy - i na odwrót: im więcej niewiadomych, tym opór jest większy. Także zakres restrukturyzacji i jej przedmiot wpływają na siłę oporu wobec zmian, w związku z tym należy starać się pozyskać ludzi do ich przeprowadzania. Do najważniejszych przyczyn oporu pojawiających się w obliczu zmian restrukturyzacyjnych respondenci zaliczyli ${ }^{1}$ :

- strach przed zwolnieniem;

- strach przed zmianą zakresu zadań i czynności oraz związaną z tym obawę, że nie podołają nowym obowiązkom;

- strach przed dołożeniem obowiązków;

- strach przed zmianą składu zespołów i konieczność przyzwyczajania się do nowych współpracowników;

- strach przed zwolnieniem z pracy koleżanki, kolegi;

- niepewność przyszłości, obniżenia zarobków itp.;

- często strach przez koniecznością podnoszenia kwalifikacji: szkolenia, kursy.

Brak informacji o zaplanowanych i przewidywanych zmianach, o ich kierunkach, zakresie, obszarze, brak jasno sprecyzowanego uzasadnienia przyczyn restrukturyzacji powoduje, że pracownicy czują się ignorowani, a tym samym często przygotowują się do stawiania oporu, wiążącego się z brakiem zaangażowania, a nawet $-\mathrm{w}$ skrajnych przypadkach $-\mathrm{z}$ aktami sabotażu. Pracownicy powinni zatem uczestniczyć w planowaniu restrukturyzacji od samego początku.

\footnotetext{
${ }^{1}$ Przebadanych zostało około 30 pracowników różnych szczebli i na różnych stanowiskach. Badania wykonane zostały w okresie 2012-2013, przy okazji przeprowadzania przez autorkę restrukturyzacji w kilku firmach należących do sektora małych i średnich przedsiębiorstw. Najczęściej restrukturyzacja dotyczyła rozwoju organizacji w związku z rozpoczęciem działalności importowej bądź eksportowej, a także zmian systemów motywacyjnych i wprowadzenia nowej technologii bądź nowych maszyn i urządzeń.
} 
Powinni także być poinformowani o możliwych zagrożeniach czy spadku wydajności, zwłaszcza w pierwszej fazie po wprowadzeniu zmiany².

W procesie restrukturyzacji należy kierować się racjonalnością metodologiczną i rzeczową, zwłaszcza w zakresie podjęcia decyzji o wyborze konkretnego rozwiązania czy sposobu jego przeprowadzenia. $\mathrm{W}$ procesie restrukturyzacji należy też uwzględnić nie tylko dobro organizacji, ale i indywidualne potrzeby oraz oczekiwania pracowników. Pominięcie tych aspektów może stać się poważną przyczyną oporu lub konfliktu organizacyjnego. W opinii pracowników nie każdy moment na przeprowadzenie restrukturyzacji jest dobry. Tym bardziej istotna staje się sytuacja, w której kierownik o odpowiedzialnej i charyzmatycznej postawie potrafi rzeczowo przedstawić przyczyny restrukturyzacji, dać rzetelną informację, podzielić zadania i zaangażować pracowników. Żadna zmiana nie jest prosta i przewidywalna, jednak należy pamiętać, że jej przeprowadzenie jest koniecznością mającą zapewnić przetrwanie organizacji, jej rozwój czy wejście na rynki innych krajów. Powód restrukturyzacji jest determinantą jej rodzaju.

\subsection{Proces restrukturyzacji firm $w$ związku z rozpoczynaniem wspólpracy międzynarodowej w świetle badań własnych}

Dojrzała gospodarka rynkowa cechuje się występowaniem zjawiska nasycenia rynku. Wymusza to na przedsiębiorcach i menedżerach firm konieczność szukania nowych rozwiązań, wśród których coraz częściej znajduje się nawiązanie współpracy zagranicznej. Takie działanie jednak wiąże się zawsze z dostosowaniem zasad, regulaminów, procedur i struktur organizacyjnych do nowych warunków. Ogólnie działania dostosowawcze związane $\mathrm{z}$ wprowadzeniem wszelkiego typu zmian i ulepszeń autorka nazywa tu restrukturyzacją lub po prostu zmianą.

Autorka, uczestnicząc w kilkunastu restrukturyzacjach w polskich firmach, zauważyła istotne różnice między rodzajem i zakresem zmian wprowadzanych w firmach, które działają lokalnie czy regionalnie a tymi, które wychodzą ze swoją działalnością na rynki zagraniczne. W przebadanych do tej pory firmach dała się zauważyć zmiana zakresu czynności i obowiązków dla pracowników odpowiedzialnych za strategię, jakość, analizę rynku, kontakty z klientami (także zagranicznymi). Działania te poparte były dogłębną analizą kompetencji osób zatrudnionych, w kierunku wyłonienia tzw. kluczowych pracowników w procesie kontaktu z klientami zagranicznymi, ale także w procesie tworzenia i przetwarzania dokumentacji oraz analizy danego rynku zagranicznego. Na zna-

${ }^{2} \mathrm{O}$ niewłaściwie przeprowadzonych restrukturyzacjach autorka pisała w: Restrukturyzacja w organizacji - konieczność i przyczyny sprzeciwu [Glinkowska 2013]. 
czeniu zyskała także obsługa księgowa i prawna. Zmiana zakresu obowiązków dotyczyła w pierwszej kolejności wyłonienia osób, które miały się zająć zbadaniem przepisów prawa na rynku danego kraju w aspekcie interesującym przedsiębiorstwo oraz zbadaniem tego rynku. Jednocześnie, pracownicy firm zostali zweryfikowani pod kątem znajomości pożądanego języka. Zwykle osoby, które biegle znały język, otrzymały status osób odpowiedzialnych za kontakt z klientami i kooperantami zagranicznymi. To kryterium, traktowane jako niezbędne, konfrontowane było z innym, traktowanym jako pożądane, którym była umiejętność nawiązywania relacji z ludźmi i ich podtrzymywania. Ważne więc stały się cechy osobowości danego pracownika. Istotna w tym względzie okazała się dobra znajomość własnych pracowników. Wydaje się, że znajomość własnych pracowników była tym lepsza, im mniejsze było przedsiębiorstwo, a kierownik bardziej angażował się w sprawy pracownicze. W jednym badanym przypadku nie znaleziono w firmie osoby spełniającej wymogi; problem ten został rozwiązany poprzez zatrudnienie właściwej osoby spoza firmy.

Transakcje dokonywane z kooperantami zagranicznymi wymagają znajomości odpowiednich i konkretnych przepisów prawa. W początkowej fazie, tzn. $\mathrm{w}$ fazie podejmowania decyzji związanych $\mathrm{z}$ wejściem na rynek zagraniczny, przedsiębiorcy (menedżerowie) korzystali z porad prawników spoza organizacji, kolejno jednak przerzucano te zadania i obowiązki na własne działy finansowo-księgowe, albo na zewnętrzne biura rachunkowe, z których usług dana firma korzystała. Nasuwa się tu konkluzja, że rozpoznanie warunków związanych $\mathrm{z}$ otoczeniem prawnym jest najbardziej istotne przed rozpoczęciem współpracy z zagranicą. Właściwe i skrupulatne rozpoznanie może być determinantą podjęcia decyzji o współpracy z przedsiębiorcą zagranicznym (taką opinię wyrazili respondenci). Po rozpoznaniu tychże, obowiązki monitorowania właściwości prawnych spadły na działy księgowe lub zewnętrzne firmy rachunkowe. $\mathrm{W}$ dwóch analizowanych przypadkach powstały też w strukturze organizacyjnej działy współpracy z zagranicą, na które nałożono obowiązek komunikowania się z klientami lub kooperantami zagranicznymi i bieżącego analizowania rynku pod względem jego preferencji i uwarunkowań polityczno-prawnych. $Z$ wywiadu przeprowadzonego $\mathrm{z}$ właścicielami tych firm i ich menedżerami wynika, że powodem tego była nie tylko potrzeba, lecz także przyjęta przez przedsiębiorstwo strategia, zakładająca kreowanie wizerunku firmy (PR) zarówno w Polsce, jak i za granicą.

Duże znaczenie w procesie wychodzenia na rynki zagraniczne ma również jakość i innowacyjność produktów/usług. W związku z powyższym zmienia się znaczenie kontroli jakości w kierunku wzrostu jej rangi i dostosowania do wymogów danego klienta. Kreatywność firm, kończąca się niejednokrotnie produktem innowacyjnym lub ulepszonym, wymaga często stworzenia odrębnych 
stanowisk do spraw badań i rozwoju. W analizowanych przypadkach nie utworzono nowych bądź odrębnych stanowisk. Obowiązki z tym związane zostały przypisane działom: marketingu i produkcji. Poszczególni pracownicy działów marketingu byli także (we współpracy z informatykami) odpowiedzialni za jakość i informacje na stronach internetowych firm. Wprowadzenie powyższych zmian wymagało przebudowania systemów motywacyjnych firm, co spotkało się z oporem pracowników. Istotnym zmianom podlegały też części firm zajmujące się logistyką, dystrybucją czy transportem. W jednym przypadku powstało nowe stanowisko zajmujące się logistyką. Charakterystyczna była próba dokonywania zmian restrukturyzacyjnych w oparciu o własne zasoby ludzkie i rzeczowe. Właściciele i kierownicy najpierw dokonywali analizy istniejących zasobów pod względem możliwości ich wykorzystania do wspólpracy z zagranicą, a następnie - wobec ich braku - szukano ich na zewnątrz organizacji.

\subsection{Podsumowanie}

Analizowane przypadki firm należących do sektora małych i średnich przedsiębiorstw pokazały, że wszystkim restrukturyzacjom towarzyszył niepokój lub opór, związany głównie ze strachem spowodowanym możliwością utraty pracy, obniżenia płac lub niepodołania nowym obowiązkom ${ }^{3}$. Badania oparte na wywiadach z pracownikami pokazały jednak błędy w procesie przeprowadzania zmian, bowiem pracownicy nie byli w odpowiedni sposób poinformowani o metodach, zakresie i konsekwencjach restrukturyzacji.

Powodem wszystkich dokonanych zmian restrukturyzacyjnych była konieczność szukania nowych możliwości w związku z „kurczącym się” rynkiem krajowym. Z tego też względu przeprowadzana (czy już przeprowadzona) w badanych firmach restrukturyzacja nosiła znamiona restrukturyzacji rozwojowej (twórczej), wiążącej się z chęcią rozwoju działalności poza granice kraju, a także restrukturyzacji dostosowawczej (adaptacyjnej), przeprowadzanej w organizacjach o malejących zyskach i malejących rynkach, jak i restrukturyzacji antycypacyjnej, opartej na koncepcji benchmarkingu. Ta sytuacja pokazała, że często rodzaj restrukturyzacji (a tym samym jej nazwa) zależy od jej przyczyn. Oznacza to również, że w jednej organizacji jest możliwe przeprowadzenie jednocześnie restrukturyzacji o różnych charakterach i przesłankach.

${ }^{3}$ Były to najczęściej wymieniane przez pracowników badanych firm powody oporu lub niepokoju w związku z przeprowadzaniem zmian restrukturyzacyjnych. 


\section{Bibliografia}

Borowiecki R., Kwieciński M. (red.), 2001, Zarządzanie zasobami informacji w przedsiębiorstwie. Ku przedsiębiorstwu przyszłości, Wyd. Naukowo-Techniczne, Warszawa.

Chandler A. D., 1962, Strategy and Structure, The MIT Press, Massachusetts Institute of Technology, Cambridge MA-London.

Duliniec A., 2007, Finansowanie przedsiębiorstwa, PWE, Warszawa.

Glinkowska B., 2013, Restrukturyzacja w organizacji - konieczność i przyczyny sprzeciwu, „Gazeta Finansowa", 11-17 października.

http://pl.wikipedia.org/wiki/Restrukturyzacja (dostęp 15.11.2013).

Kaczmarek B., Sikorski Cz., 1999, Podstawy zarządzania. Zachowania organizacyjne, wyd. 2 poszerz., Wyd. Absolwent Sp. z o.o., Łódź.

Peszko A., 2002, Elementy organizacji i zarządzania przedsiębiorstwem, wyd. 4 popr., Uczelniane Wydawnictwa Naukowo- Dydaktyczne, Kraków

Porada-Rochoń M. (red.), 2009, Restrukturyzacja przedsiębiorstw w procesie adaptacji do wspótczesnego otoczenia. Perspektywa międzynarodowa, Difin, Warszawa.

Stabryła A., 2000, Zarządzanie strategiczne w teorii i praktyce firmy, PWN, Warszawa-Kraków. Suszyński C., 2003, Restrukturyzacja, konsolidacja, globalizacja przedsiębiorstw, PWE, Warszawa. Styn I., 2012, Sposoby restrukturyzacji banków. Analiza porównawcza i wnioski na przyszłość, Wyd. Zeszyty Naukowe PTE, Kraków.

Zieleniewski J., 1976, Organizacja zespołów ludzkich, PWN, Warszawa.

\section{Beata Glinkowska}

\section{RESTRUCTURING OF COMPANIES ENTERING INTO FOREIGN MARKETS}

(Abstract)

The chapter, based on literature review and own research study, includes selected issues related to the restructuring of companies in relation to their entering foreign markets. Firstly, the objective and the scope of the study are defined. In the following sections, the concept of organizational structure and restructuring is explained. Subsequently, the essence of restructuring types, found in the literature is explained in details. Also, the recapitulation of reasons for restructuring in the SME sector companies is presented, and the causes of resistance to change are examined. The chapter presents also an attempt to determine the specifics of the restructuring of companies (in this selected sector) entering foreign markets. A brief summary ends the chapter. 